\title{
Equation for Calculating Evapotranspiration of Technical Soils for Urban Planting
}

\author{
Oliver Weiss*D, Pia Minixhofer (D), Bernhard Scharf and Ulrike Pitha \\ Department of Civil Engineering and Natural Hazards, Institute of Soil Bioengineering and Landscape \\ Construction, University of Natural Resources and Life Sciences, Peter-Jordan-Strasse 82, A-1190 Vienna, Austria; \\ pia.minixhofer@boku.ac.at (P.M.); bernhard.scharf@boku.ac.at (B.S.); ulrike.pitha@boku.ac.at (U.P.) \\ * Correspondence: oliver.weiss@boku.ac.at
}

check for updates

Citation: Weiss, O.; Minixhofer, P.; Scharf, B.; Pitha, U. Equation for Calculating Evapotranspiration of Technical Soils for Urban Planting. Land 2021, 10, 622. https://doi.org/ 10.3390/land10060622

Academic Editors: Manfred Koehler and Daniel Kaiser

Received: 17 May 2021

Accepted: 9 June 2021

Published: 10 June 2021

Publisher's Note: MDPI stays neutral with regard to jurisdictional claims in published maps and institutional affiliations.

Copyright: (c) 2021 by the authors. Licensee MDPI, Basel, Switzerland. This article is an open access article distributed under the terms and conditions of the Creative Commons Attribution (CC BY) license (https:/ / creativecommons.org/licenses/by/ $4.0 /)$.

\begin{abstract}
Equations for calculating evapotranspiration in technical soils show great differences regarding their results. Causes are the different climatic conditions and vegetation specifics during their development. Every equation of evapotranspiration only delivers $100 \%$ correct results if it is used under the same climatic condition as it was developed in. To determine the evapotranspiration, the loss of weight of different technical soils and plants was measured in a test series on load cells in a climate chamber. The result of these test series is the development of an easy-to-use equation. An equation for calculating evapotranspiration at any temperature is possible while using a polynomial correlation. To determine the evapotranspiration rate (in $\mathrm{mm} / \mathrm{m}^{2}$ per $24 \mathrm{~h}$ ), only temperature, vegetation type, and technical soil have to be defined to obtain an output of evapotranspiration in $\mathrm{mm} /$ day. Using the well-known equation by Makkink, evapotranspiration in technical soils is $0.12 \mathrm{~mm} /$ day, whereas the newly developed equation calculates (1) $2.59-5.58 \mathrm{~mm} /$ day for the variant with no vegetation, (2) 3.15-4.00 mm/day for Sedum floriferum, (3) $4.40-4.55 \mathrm{~mm} /$ day for Geranium $x$ cantabrigiense. The application of this equation will help to determine the evapotranspiration in chosen technical soils (used in the sector of rainwater management) with or without vegetation.
\end{abstract}

Keywords: evapotranspiration; green infrastructure; rainwater management; nature-based stormwater management; Vienna

\section{Introduction}

The on-going climate crisis leads to an increase of heavy rainfall events and a higher risk of longer dry periods [1-3]. Although green infrastructure could cope with the intensified stormwater events, urban development has been practiced for years without including them [4]. Green infrastructures, such as bioswales or raingardens, are permeable and have a high impact on evapotranspiration, which influences the urban climate enormously [5-7].

Evapotranspiration can be described as the sum of water loss by soil surface (evaporation) and the water loss by plants (transpiration) [8]. The urban water cycle is heavily influenced by the high sealing rate and the decreasing infiltration capacity of the remaining open surfaces [9]. Heavy rainfall events hit the surface and spark fine particles, which cover the soil surface and change the soil structure [10]. In combination with the intensive input of many other external fine particles (e.g., tire wear particles from streets, sediments from close-by surfaces), the soil gets compacted [11]. The decreasing infiltration rate and higher surface water runoff [10] impacts further on the overall evapotranspiration rate.

To adapt to these extreme conditions, plantings in cities demand new solutions for technical soils with specific features concerning their composition. Technical soils, as defined for this article, are mineral planting substrates with characteristics of high infiltration rate, water absorption capacity, and pore volume [12,13]. These technical soils aim to be water permeable for many years without any decrease in infiltration rate [14] and are, therefore, often used for sustainable urban rainwater systems, ensuring the vital development of trees, shrubs, and perennials [12,15]. 
In standards for infiltration systems [16,17] and tree plantings [18], the infiltration rates for soils are described and regulated, but no information on the potential rate of evapotranspiration is available. Therefore, a very important field of application for evapotranspiration equations is rainwater management in urban areas. A large variety of different equations for calculating evapotranspiration exists, as already explained in-depth in the publication "Evapotranspiration of Technical soils-Methodology for calculating evapotranspiration of technical soils" [19]. Existing equations, such as the most famous combination equation by Penman [20], only delivers $100 \%$ correct results in conditions (such as vegetation, natural grown soil, climatic conditions, etc.) they were developed in. For technical soils, the provided results are not acceptable because of the poor transferability of evapotranspiration equations, which were all developed in natural grown soils $[13,21,22]$.

Therefore, the creation of a new equation for technical soils is described in this publication. First, a test series was developed to assure the newly developed equation is applicable for different technical soils with or without vegetation. Then, the gained results were used to develop the new equation for the calculation of the evapotranspiration. To underline the relevance of the developed equation, the calculation was compared to the results of the well-known equation of radiation by Makkink (developed for natural grown soil). The results of this equation are specially determined for grass, which has no shortage of water [23]. In comparison to the well-known equation of Penman, the equation of radiation by Makkink is more easily applicable, due to the simpler measurements of the needed parameters. The equation of radiation by Makkink is an adaption of Penman's equation for Europe [24,25].

Evapotranspiration is influenced by transpiration of plant and evaporation of soil.

Solar radiation, air temperature, wind speed, and relative air humidity are the key factors influencing transpiration [26]. Up to a certain saturation point, photosynthesis increases with increasing irradiance. Depending on photosynthesis type and plant species, there are various differences in saturation points depending on air temperature and global radiation. The longer and higher radiation is available, the longer the plant can open its stomata and the gas exchange can take place. For photosynthesis to occur, a certain minimum temperature must be present. Generally, with the exception of specially adapted plants, the minimum temperature is around $0{ }^{\circ} \mathrm{C}$. The higher the temperature rises, and provided that no other processes act as limiting factors, the more productive photosynthesis becomes. The evaporation chill caused by the transpiration of the plant can keep the temperature of the leaves up to $15^{\circ} \mathrm{C}$ below the ambient air temperature [27]. The humidity of the atmosphere also plays a significant role in transpiration. Water vapor is diffused through the epidermis until the vapor pressure within the plant and the surrounding atmosphere is the same. Since the humidity in the atmosphere is usually much lower than that inside the plant, diffusion is only possible until the plant does not receive a water supply from the soil. Whether plant-available water prevails in the soil depends, among other things, on the binding forces in the soil. The capillary forces of the soil cavities, the surface forces of the soil colloids, and the osmotic forces of the nutrients dissolved in the soil play a major role. As water is consumed and the soil dries out, it becomes increasingly difficult for the plant to obtain water. In windy conditions, water vapor and dry air are carried away more quickly. Thus, there remains a persistently higher water vapor pressure. As mentioned above, the effect of wind can also be reduced by special adaptations. For example, by recessed stomata or stomata covered with trichomes [20].

Evaporation is influenced by meteorological, biochemical, and landscape-specific influencing factors. Meteorological parameters are the same, as explained above. Solar radiation, air temperature, wind speed, and relative air humidity significantly influence evaporation. Important biochemical parameters are the water content of the soil, depth of the groundwater surface, and the respective soil type. The soil type determines further soil physical properties [20]. Landscape-specific influencing factors include topography, vegetation, and surrounding structures. Depending on the exposure, vegetation density, 
and surrounding structures of soils, soil surfaces are exposed to different climatic conditions. Thus, there is an influence and associated change in evaporation. The soil type determines further soil physical properties. Evaporation decreases as the soil dries out. There are clear differences between sandy and clayey soils. For example, the evaporation rate decreases faster in light sandy soils than in heavy loamy soils [20]. The reason for this is that in grainy soils, such as gravel or sandy soils, the surface dries quickly and the coarse soil material has a high hydraulic conductivity, which means that hardly any water can be supplied to the soil surface. Soils with a higher proportion of fine grains have a significantly lower hydraulic conductivity and thus store water much better than those with a high proportion of coarse grains. Depending on the grain size of the soil materials and the associated hydraulic conductivity, groundwater can reach the soil surface from different depths [28]. In vegetated soils with a closed vegetation layer, evaporation amounts to less than $5 \%$ of the total evapotranspiration [29]. The example presented profound and comprehensive knowledge that originates from research based on natural soils. Technical soils on the other hand do not match natural soils regarding many aspects, e.g., soil layers, grain size distribution, grain size composition, hydrologic properties, pore volumes, and biochemical properties. To enable the application of nature-based solutions in urban spheres as a measure to counteract the impact of global warming, it is necessary to transform the soil research-based knowledge to technical soils.

In this research work, we test the hypothesis that great differences in evapotranspiration between the equation of radiation by Makkink and the newly developed equation for evapotranspiration are expected.

The successful transformation of urban areas from grey to green needs profound planning and design. The knowledge of water demand of different plant species, the provision of water, and hydrologic properties of technical soils are core design parameters that need to be considered.

Thus far, no other work known to the authors dealt with the creation of an easily applicable equation for calculating evapotranspiration in technical soils. Many studies investigating the evapotranspiration properties of natural soils used load cells [30,31]. This approved methodology has been chosen for this research work, but the natural soil has been exchanged with technical soils. A comparison study showed that the radiation-based equations were found to perform best in calculating evapotranspiration because they are producing a similar pattern as the Penman-Monteith method [32]. Especially, the equation by Makkink was identified to perform best under the radiation-based ones under drier climatic conditions. It was found that the equations and their outcomes vary significantly depending on the climatic conditions of the region where they have been developed [20,32] Accordingly, they cannot be easily applied in other climatic regions.

Therefore, easily applicable equations were created to determine evapotranspiration for different technical soils and plants and compared to the also comparatively easily applicable Makkink equation. The newly developed equations may be adapted to different required climatic conditions and technical soils, while using the proposed method.

\section{Materials and Methods}

Three main steps were necessary to create the new equation for calculating evapotranspiration. The first and second step were described in a previous paper by Weiss et al. [19]. Information about test set-up and the test series in the climate chamber were described in detail. A short overview of the information given in the previous paper, will be presented in Sections 2.1 and 2.2.

In this article, we built on these results and developed in the third step the equation itself. Therefore, a selection of well-known equations was taken, and their results were compared. A comparative analysis of the basics of evaporation, transpiration, and evapotranspiration revealed the different influencing factors on these three processes. Afterwards, a test series of different technical soils and plants on load cells in a climate chamber led to 
the development of the new equation using polynomial trend lines for evapotranspiration of different technical soils and plants in various climate scenarios.

The test set-up, test series, and the development of the equations is described briefly in the following. Three repetitions were performed for each technical soil and plant in each of the three climate scenarios. Overall, there were nine values of evapotranspiration for each technical soil and plant, which were inserted in the polynomial trend line [19].

The process of evapotranspiration depends, as described above, on several framework conditions, e.g., air temperature, relative air humidity, type of photosynthesis, water provision. According to the fact that plant species reach saturation of photosynthetic performance, a linear or potential equation has been eliminated from consideration to calculate the evapotranspiration. Given the example of the soil moisture equation of capacitive sensors, the polynomial trend line has been chosen for the equations. Equations for soil moisture measurements are typically polynomial functions of second or third degree, depending on soil type. The polynomial trend line of second degree was used due to the least deviations within the measured results in evapotranspiration. However, representative values can only be excepted between minimum and maximum air temperature of chosen climate scenarios simulated in the test series, due to the characteristics of polynomial trend lines.

\subsection{Test Set-Up}

The test set-up is already described in detail in the paper "Evapotranspiration of Technical soils-Methodology for calculating evapotranspiration of technical soils" [19]. Here, a short summary of the test set-up is given once more for a better understanding of the processes, which led to the equation for calculating evapotranspiration.

To develop an equation for calculating evapotranspiration, three important climatic scenarios were simulated in a climate chamber. Therefore, the relative air humidity was constantly at $50 \%$ and the radiation of sun light with an illumination level of $50 \mathrm{~W} / \mathrm{m}^{2}$ [33] was also constantly simulated from 06:00 a.m. to 06:00 p.m. (CET). The average temperature of a city such as Vienna $\left(48^{\circ} 12^{\prime} \mathrm{N} 16^{\circ} 22^{\prime} \mathrm{E}\right.$ in oceanic climate), with $11.7^{\circ} \mathrm{C}$, represents scenario I [34]. A meteorologically defined summer day with a temperature of $25^{\circ} \mathrm{C}$ is analyzed in scenario II [35]. Scenario III offers an extremely hot day with a temperature of $35{ }^{\circ} \mathrm{C}[36]$.

The used plant containers contained a volume of $10 \mathrm{~L}$ and were filled with the desired technical soils. To prevent the soil from being flushed out, a fleece $\left(100 \mathrm{~g} / \mathrm{m}^{2}\right)$ surrounded the bottom of the containers. The test set-up consisted of three replicates for each combination of technical soils with and without vegetation. In this test series, some of the usually used C3 (Geranium $x$ cantabrigiense) and CAM (Sedum floriferum 'Weihenstephaner Gold') plants in raingardens were selected. The main difference of C3 and CAM plants is the type of photosynthesis (the optimum in temperature and the coefficient of transpiration) [27], as shown in Table 1.

Table 1. Overview of the type of photosynthesis of $\mathrm{C} 3$ and CAM plants with differences in optimum in temperature and coefficient of transpiration (based on Weiler et al., 2008 [27]).

\begin{tabular}{ccc}
\hline Type of Photosynthesis & C3 & CAM \\
\hline Optimum in temperature & $30-40{ }^{\circ} \mathrm{C}$ & $20-35{ }^{\circ} \mathrm{C}$ \\
Coefficient of transpiration & $<350$ & $30-50$ \\
\hline
\end{tabular}

\subsection{Test Series}

In the climate chamber, load cells were located for recording changes in weight. The precision of load cells during the whole test series was in grams and data were measured in intervals of $10 \mathrm{~s}$ and formed to a mean value in intervals of $60 \mathrm{~s}$. Technical data of the used load cells can be found in the following Table 2. Each of the soil combinations were positioned on a separate load cell and remained for exactly $24 \mathrm{~h}$ in the climate chamber. After $24 \mathrm{~h}$, the next soil combination replaced the existing ones. Each soil combination was 
placed in the climate chamber at least three times per scenario and any soil combination was combined with the others, which was necessary to eliminate reciprocal effects.

Table 2. Overview of technical data of used load cells (based on Hottinger Baldwin Messtechnik $\mathrm{GmbH}[37])$.

\begin{tabular}{cc}
\hline Parameters & Specific Data of Used Load Cells \\
\hline type & PW10AC3MR \\
maximum capacity $\left(\mathrm{E}_{\max }\right)$ & $100 \mathrm{~kg}$ \\
minimum capacity $\left(\mathrm{E}_{\min }\right)$ & $0 \mathrm{~kg}$ \\
minimum verification interval $\left(\mathrm{v}_{\min }\right)$ & $10 \mathrm{~g}$ \\
max. platform size & $600 \times 500 \mathrm{~mm}$ \\
sensitivity $\left(\mathrm{C}_{\mathrm{n}}\right)$ & $2.0+-0.2 \mathrm{mV} / \mathrm{V}$ \\
\hline
\end{tabular}

Table 3 gives an overview of the different soil combinations, which were analyzed with and without planting, and also shows the combination of different technical soils, which were tested only without any vegetation.

Technical soil A and B are already used in different raingardens (planted with perennials) in Ober-Grafendorf, Austria [38], and technical soil C is a standard technical soil usually used in Vienna for planting street trees. Technical soils D and $\mathrm{E}$ are newly developed technical soils for the research project SAVE, which are also used for tree plantings to generate better living conditions for street trees [39]. Substrate F is another technical soil for raingardens. Technical soils $\mathrm{C}-\mathrm{F}$ are specially designed for the infiltration of stormwater runoff and are used in a test series for rainwater management in the City of Vienna (Austria). The used technical soils were designed according to the requirements of ÖNORM B 2506-3 [16].

Table 3. Overview of the different combinations of technical soils (A-F). Each technical soil is filled into three $10 \mathrm{~L}$ plant containers with three replicates (a-c) with CAM plants, C3 plants, and no plants (based on Weiss, 2017 [40]).

\begin{tabular}{ccc}
\hline & Repetitions & \\
\hline CAM Plants & C3 Plants & No Plants \\
\hline A_Sedum $_{\text {A }}$ & A_Geranium $_{\mathrm{A}}$ & $\mathrm{A}_{\mathrm{A}}$ \\
A_Sedum $_{\mathrm{B}}$ & A_Geranium $_{\mathrm{B}}$ & $\mathrm{A}_{\mathrm{B}}$ \\
A_Sedum $_{\mathrm{C}}$ & A_Geranium $_{\mathrm{C}}$ & $\mathrm{A}_{\mathrm{C}}$ \\
B_Sedum $_{\mathrm{A}}$ & B_Geranium $_{\mathrm{A}}$ & $\mathrm{B}_{\mathrm{A}}$ \\
B_Sedum $_{\mathrm{B}}$ & B_Geranium $_{\mathrm{B}}$ & $\mathrm{B}_{\mathrm{B}}$ \\
B_Sedum $_{\mathrm{C}}$ & B_Geranium $_{\mathrm{C}}$ & $\mathrm{B}_{\mathrm{C}}$ \\
& & $\mathrm{C}_{\mathrm{A}}$ \\
& & $\mathrm{C}_{\mathrm{B}}$ \\
& & $\mathrm{C}_{\mathrm{C}}$ \\
& & $\mathrm{D}_{\mathrm{A}}$ \\
& & $\mathrm{D}_{\mathrm{B}}$ \\
& & $\mathrm{D}_{\mathrm{C}}$ \\
& & $\mathrm{E}_{\mathrm{A}}$ \\
& & $\mathrm{E}_{\mathrm{B}}$ \\
& & $\mathrm{E}_{\mathrm{C}}$ \\
& & $\mathrm{F}_{\mathrm{A}}$ \\
& & $\mathrm{F}_{\mathrm{B}}$ \\
& & $\mathrm{F}_{\mathrm{C}}$ \\
\hline
\end{tabular}

The maximum saturation of the used technical soils was tested according to the Green Roof Guidelines of the FLL [41]. The procedure was slightly modified based on a lot of experience with the performance of technical soils. Therefore, different substrate combinations were placed in a water bath for two hours (instead of four hours as described in the Green Roof Guidelines [41]). The water level was $5 \mathrm{~cm}$ above the technical soil's 
surface. Afterwards, the containers had to drip off for another two hours (instead of four hours as described in Green Roof Guidelines [41]). After the whole procedure, which lasts four hours in total, the plant containers were placed on the load cells in the climate chamber [19].

\subsection{Equation Development}

After the test series, data were analyzed. Therefore, the differences in weight (kilograms equate to liters) with a precision of grams was determined every $24 \mathrm{~h}$ for each of the technical soil combinations on the load cells.

On the basis of the loss in weight in liters per $24 \mathrm{~h}$, we developed equations for calculating evapotranspiration. As equations only deliver correct results under the conditions they were created in [20-22], each technical soil combination calls for a separate equation.

By using a polynomial trend line with the newly developed equation, evapotranspiration in liters for each soil combination within a $24 \mathrm{~h}$ day and for any chosen temperature can be easily calculated. Through insertion of any chosen $\mathrm{x}$-value for the temperature, the created equation delivers a y-value for the evapotranspiration in liters per $24 \mathrm{~h}$ in the analyzed containers. To determine evapotranspiration of a technical soil per $\mathrm{m}^{2}$, the equation has to be divided by the surface area $\left(0.0593957 \mathrm{~m}^{2}\right)$ of the used containers.

The equations for calculating evapotranspiration are described in detail in Section 3.

\subsection{Comparison with the Radiation Equation by Makkink}

The well-known equation by Penman needs many different and complex parameters to calculate the evapotranspiration. The radiation equation by Makkink is an adaption and simplification of this equation for Europe [25,41].

The used input parameters for calculating evapotranspiration using the radiation equation by Makkink are extraterrestrial radiation $(R a)$, average monthly sunshine duration $(n)$, maximum sunshine duration $(N)$, monthly wind velocity $(U m)$, relative air humidity $(\mathrm{Rhm})$, and an auxiliary table delivering a temperature-depending input value [20].

In contrast, the newly developed equation (while choosing the corresponding technical soil and planting) only needs the parameter "air temperature" as an input value.

Table 4 gives an overview of the different parameters used in the radiation equation by Makkink and the newly developed equation.

In the following Figure 1, a summarized overview for better understanding of the processes taken for the research work, is given.
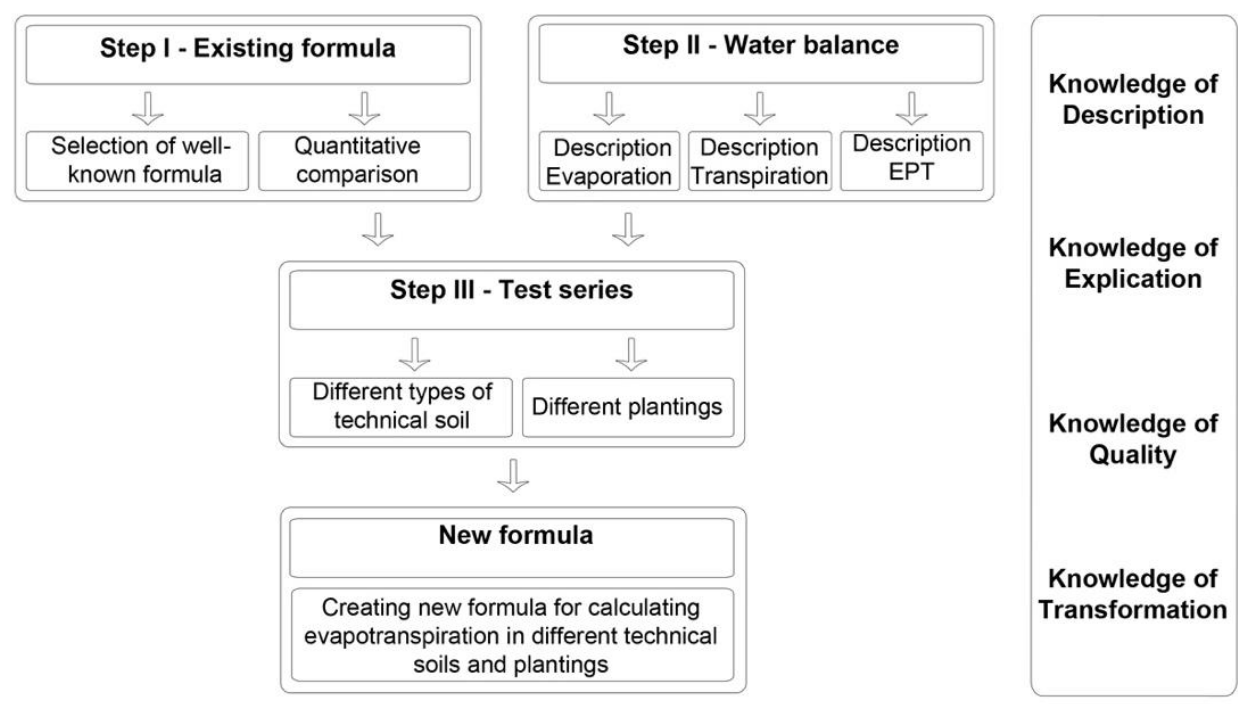

Figure 1. Overview of the used research design (based on Weiss et al., 2019 [19]). 
Table 4. Comparison of input parameters between the radiation equation by Makkink and the newly developed equation.

\begin{tabular}{cc}
\hline Radiation Equation by Makkink & Newly Developed Equation \\
\hline average monthly air temperature $(T)$ & average monthly air temperature $(T)$ \\
extraterrestrial radiation $(R a)$ & \\
average monthly sunshine duration $(n)$ & \\
maximum sunshine duration $(N)$ & \\
monthly wind velocity $(\mathrm{Um})$ & \\
relative air humidity $(R h m)$ & \\
input value using an auxiliary table & \\
\hline
\end{tabular}

\section{Results}

In the following, equations are presented for calculating evapotranspiration in different chosen substrates (used for rainwater management) with or without any type of planting.

\subsection{Equation for Calculating Evapotranspiration}

Figures 2-4 show the development of equations for calculating evapotranspiration, using polynomial regression lines for describing the height of evapotranspiration (see Section 2.1) per $24 \mathrm{~h}$ (e.g., technical soil A and B).

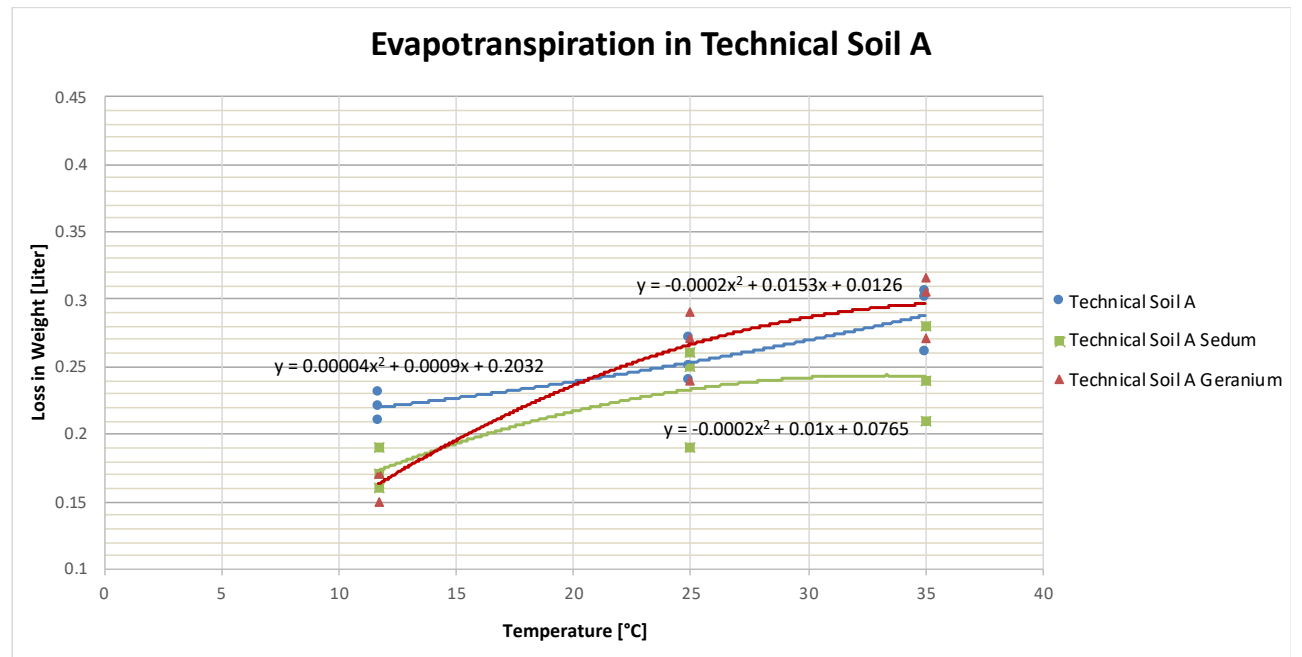

Figure 2. Regression lines were inserted through the differences in weight of any soil combination of technical soil A (with and without planting) in climate scenario I, II, and III, to create equations for calculating evapotranspiration (based on Weiss, 2017 [40]).

Figure 2 shows the evapotranspiration of technical soil A without any type of planting compared to the planted version with Sedum floriferum 'Weihenstephaner Gold' and with Geranium $x$ cantabrigiense in the used 10 L containers. Figure 3 presents the evapotranspiration of technical soil $\mathrm{B}$ without any greenery compared to the planted containers with Sedum floriferum 'Weihenstephaner Gold' and Geranium $x$ cantabrigiense. Figure 4 shows the evaporation of the technical soils D-F, without any planting.

The equations follow the principal of a polynomic regression of the second degree (E0):

$$
\mathrm{y}=\frac{\mathrm{a} * \mathrm{x}^{2}+\mathrm{b} * \mathrm{x}+\mathrm{c}}{\mathrm{d}}
$$

y represents evapotranspiration ( $\mathrm{mm} /$ day);

$\mathrm{x}=$ the chosen temperature $\left({ }^{\circ} \mathrm{C}\right)$;

$\mathrm{a}, \mathrm{b}$, and $\mathrm{c}=$ the constants of the corresponding equation; 
$\mathrm{d}=$ the equation has to be divided by the surface area $\left(0.0593957 \mathrm{~m}^{2}\right)$ of the used containers to determine evapotranspiration of a technical soil per $\mathrm{m}^{2}$.

\section{Evapotranspiration in Technical Soil B}

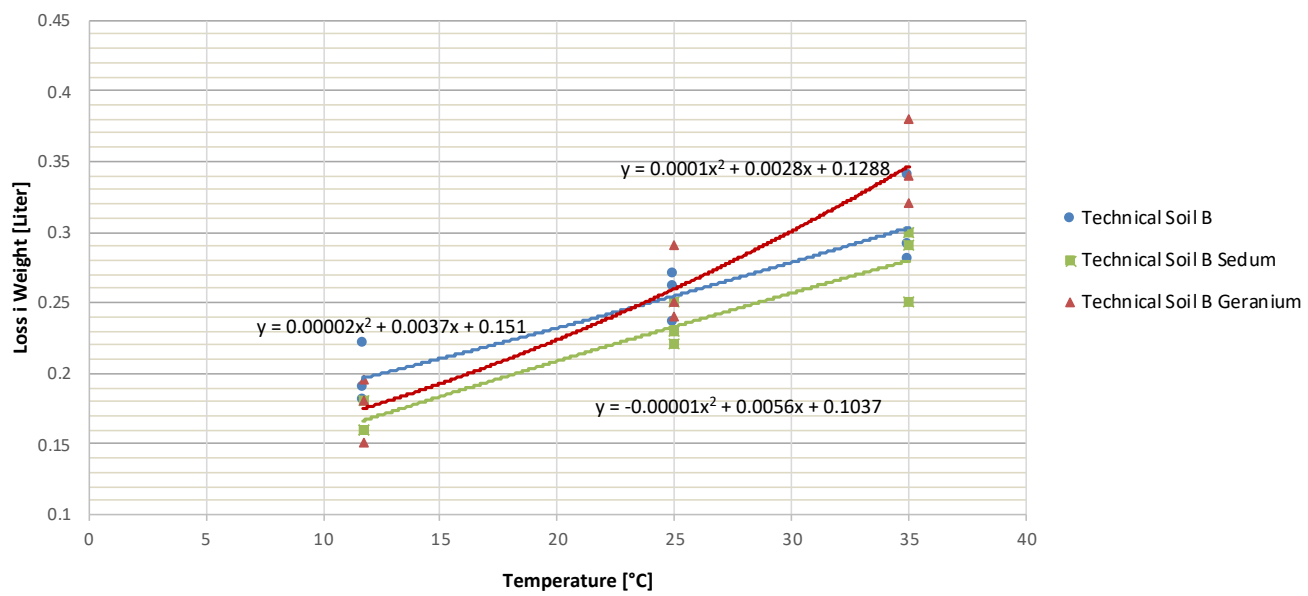

Figure 3. Regression lines were inserted through the differences in weight of any soil combination of technical soil B (with and without planting) in climate scenario I, II, and III, to create equations for calculating evapotranspiration (based on Weiss, 2017 [40]).

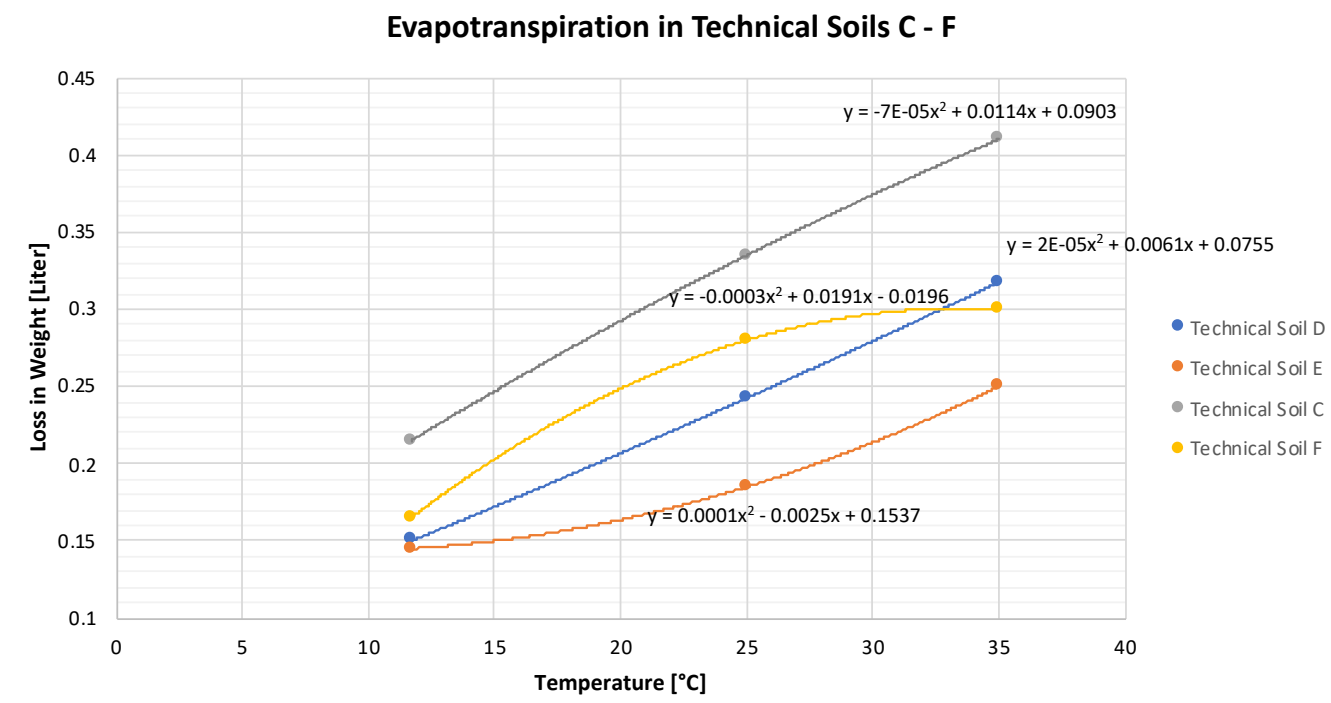

Figure 4. Regression lines were inserted through the differences in weight of any technical soil C-F in climate scenario I, II, and III, to create equations for calculating evapotranspiration.

These results led to the following equation for calculating evapotranspiration:

(E1) Equation for calculating evapotranspiration of unplanted technical soil A:

$$
\mathrm{y}=\frac{0.00004 * \mathrm{x}^{2}+0.0009 * \mathrm{x}+0.2032}{0.0593957}
$$

(E2) Equation for calculating evapotranspiration of Sedum floriferum planted technical soil A:

$$
\mathrm{y}=\frac{-0.0002 * \mathrm{x}^{2}+0.01 * \mathrm{x}+0.0765}{0.0593957}
$$

(E3) Equation for calculating evapotranspiration of Geranium $x$ cantabrigiense planted technical soil A:

$$
\mathrm{y}=\frac{-0.0002 * \mathrm{x}^{2}+0.0153 * \mathrm{x}+0.0126}{0.0593957}
$$


(E4) Equation for calculating evapotranspiration of unplanted technical soil B:

$$
\mathrm{y}=\frac{0.00002 * \mathrm{x}^{2}+0.0037 * \mathrm{x}+0.151}{0.0593957}
$$

(E5) Equation for calculating evapotranspiration of Sedum floriferum planted technical soil B:

$$
\mathrm{y}=\frac{-0.00001 * \mathrm{x}^{2}+0.0056 * \mathrm{x}+0.1037}{0.0593957}
$$

(E6) Equation for calculating evapotranspiration of Geranium $x$ cantabrigiense planted technical soil B:

$$
\mathrm{y}=\frac{0.0001 * \mathrm{x}^{2}+0.0028 * \mathrm{x}+0.1288}{0.0593957}
$$

In the following, equations for non-planted technical soils C, D, E, and F are presented:

(E7) Equation for calculating evapotranspiration of unplanted technical soil C (standard technical soil usually used in Vienna for planting street trees):

$$
\mathrm{y}=\frac{-0.00007 * \mathrm{x}^{2}+0.0114 * \mathrm{x}+0.0903}{0.0593957}
$$

(E8) Equation for calculating evapotranspiration of unplanted technical soil D (advanced technical soil used for street trees in raingardens):

$$
\mathrm{y}=\frac{0.00002 * \mathrm{x}^{2}+0.0061 * \mathrm{x}+0.0755}{0.0593957}
$$

(E9) Equation for calculating evapotranspiration of unplanted technical soil E (another advanced technical soil used for street trees in raingardens):

$$
\mathrm{y}=\frac{0.0001 * \mathrm{x}^{2}-0.0025 * \mathrm{x}+0.1537}{0.0593957}
$$

(E10) Equation for calculating evapotranspiration of unplanted technical soil F (advanced technical soil used for seeding-greenery in raingardens):

$$
\mathrm{y}=\frac{-0.0003 * \mathrm{x}^{2}+0.0191 * \mathrm{x}-0.0196}{0.0593957}
$$

The following Table 5 shows the differences in evapotranspiration, depending on the used technical soil or planting.

Table 5. Overview in evapotranspiration per $\mathrm{m}^{2}$ of the used technical soils A-F (A and B non-planted, planted with Sedum floriferum and Geranium $x$ cantabrigiense, and C-F non-planted), while using the newly developed equations (E1-E10).

\begin{tabular}{ccc}
\hline Type of Substrate & ETP (mm/day) & ETP (mm/month) \\
\hline A non-planted (E1) & 3.43 & 102.92 \\
A (Sedum floriferum) (E2) & 3.15 & 94.50 \\
A (Geranium x cantabrigiense) (E3) & 4.55 & 136.42 \\
B non-planted (E4) & 4.31 & 129.30 \\
B (Sedum floriferum) (E5) & 4.00 & 119.93 \\
B (Geranium x cantabrigiense) (E6) & 4.40 & 131.98 \\
C non-planted (E7) & 5.58 & 167.46 \\
D non-planted (E8) & 4.05 & 121.47 \\
E non-planted (E9) & 2.59 & 77.63 \\
F non-planted (E10) & 4.55 & 136.58 \\
\hline
\end{tabular}




\subsection{Comparison with the Equation of Radiation by Makkink}

To underline the relevance of the developed equation, the evapotranspiration was assessed by comparing the well-known equation of radiation by Makkink and the here established Equations (E0-E10).

As an example, the data of the technical soil A planted with Sedum floriferum (E2), shown in Table 6, was used to determine the evapotranspiration with the two different equations. The radiation equation by Makkink is designed to calculate evapotranspiration for natural grown soils and a vegetation of short grass [42]. The result cannot be transferred to technical soils with any other kind of planting, as it will only deliver $100 \%$ correct results for this type of substrate and vegetation.

Table 6. Data for comparing the newly developed equation with the already existing equation of radiation by Makkink.

\begin{tabular}{cc}
\hline Parameter & Data \\
\hline global radiation $(r)$ & $50 \mathrm{~W} / \mathrm{m}^{2}$ \\
sunshine duration $(n)$ & $12 \mathrm{~h}$ \\
maximum sunshine duration $(N)$ & $12 \mathrm{~h}$ \\
average monthly air temperature $(T)$ & $25^{\circ} \mathrm{C}$ \\
relative air humidity $(R h m)$ & $50 \%$ \\
average monthly wind velocity $(U m)$ & $1 \mathrm{Bft}($ equates $0.51-2.06 \mathrm{~m} / \mathrm{s})$ \\
\hline
\end{tabular}

The following Table 6 shows an overview of the input parameters for calculating evapotranspiration with the equation of radiation by Makkink. Here, we used exactly the same data for sunshine duration, average monthly temperature, relative air humidity, and average monthly wind velocity, as for calculation of evapotranspiration by Equations E1-E10 in Table 5.

We calculated the evapotranspiration with the equation of radiation by Makkink [20]:

1. Determination of the evapotranspiration equivalent of extraterrestrial radiation $R a$ using an auxiliary table [20].

To calculate $R a$, global radiation $\mathrm{r}$ of $50 \mathrm{~W} / \mathrm{m}^{2}$ has to be converted to $\mathrm{mm} /$ day. Therefore, $\mathrm{W} / \mathrm{m}^{2}$ are transformed to $\mathrm{J} / \mathrm{cm}^{2}=216 \mathrm{~J} / \mathrm{cm}^{2}$.

According to the auxiliary table, extraterrestrial radiation $R a$ is about $0.88 \mathrm{~mm} /$ day.

2. Identification of the relation between average monthly sunshine duration $n$ and the maximum sunshine duration $N$.

$$
\frac{n}{N}=\frac{12}{12}=1
$$

3. Calculation of total radiation $R s$, using the following equation.

$$
\begin{gathered}
R s=R a *\left[0.2+0.5 *\left(\frac{n}{N}\right)\right] \\
R s=0.88 *[0.2+0.5 * 1] \\
R s=0.616 \mathrm{~mm} / \text { day }
\end{gathered}
$$

4. While using another auxiliary table [20], the following value is defined by an average monthly temperature of $T=25^{\circ} \mathrm{C}$.

$$
\frac{s}{s+\gamma}=0.741
$$

5. Using the average monthly wind velocity $U m=1 \mathrm{Bft}$ and relative air humidity $\mathrm{Rhm}=50 \%$, the coefficient $b$ is determined using the equation mentioned below: 


$$
\begin{gathered}
b=1.165+0.043 * U m-0.00575 * R h m \\
b=1.165+0.043 * 1-0.00575 * 50 \\
b=0.9205
\end{gathered}
$$

6. The following radiation equation by Makkink calculated the evapotranspiration (ETP) using the already determined parameters in (a) to (e):

$$
\begin{gathered}
\text { ETP }=-0.3+b * \frac{s}{s+\gamma} * R s \mathrm{~mm} / \text { day } \\
\mathrm{ETP}=-0.3+0.9205 * 0.741 * 0.616 \mathrm{~mm} / \text { day }
\end{gathered}
$$

Finally, the calculation of evapotranspiration (ETP) using the equation of radiation by Makkink delivers the following result:

$$
\mathrm{ETP}=0.12 \mathrm{~mm} / \text { day and } 3.60 \mathrm{~mm} / \mathrm{month}
$$

\section{Discussion}

The newly developed equations (E1-E10) deliver great differences in results compared to the equation of radiation by Makkink. Using the new equations (E1-E10) for calculating evapotranspiration in technical soils, the evapotranspiration per day nearly correlated with the evapotranspiration of a whole month by using the equation of radiation by Makkink (see Table 4). The main reason is the poor transformability of equations developed in natural grown soils compared to technical soils, because each equation only delivers $100 \%$ correct results under the conditions it was developed in [20].

However, compared to the results of the radiation equation by Makkink, all of the newly developed equations (E1-E10) showed similar results. These equations can be used to gain a quick and valid first insight and estimate of the evapotranspiration of each technical soil. If more precise information about evapotranspiration is needed, evapotranspiration for each technical soil and plant used in this study can be determined by using the presented method. As a result, it is clear that there is a loss of accuracy due to the strong simplification of the calculation of evapotranspiration, while only using air temperature as a key factor, which should be clearly mentioned as a strong weakness of the equations. As mentioned in the introduction, evapotranspiration is a physical process determined by many different parameters $[20,26]$. However, the main advantage of the proposed equations is that they deliver more precise results in evapotranspiration for the chosen technical soils than already existing well-known equations. Additionally, they offer the possibility to gain a first and quick insight into evapotranspiration. Furthermore, they are really easily applicable, even for non-professionals. Additional parameters (as wind speed, relative air humidity, global radiation, and of course, a larger variation of different technical soils and plants) could make the equations more precise. It needs to be assessed if simulations with tighter measured values for temperature, wind speed, or solar radiation are beneficial or unnecessarily cumbersome. We expect no additional benefit as the equations will become more and more complex with each added parameter, which will complicate the application. The focus on technical soil, vegetation, and temperature simplified the equation to include all essential parameters.

As air temperature is the only determining factor in the developed equations, results can be theoretically transferred to other climates. However, air temperature, wind speed, relative air humidity, and the global radiation depend on region and climate. Thus, cities in different climates will show large differences to the height of input parameters, which will affect the results. To ensure a better fitting of the results, input parameters should be changed in test series conducted in the climate chamber and adapted to the intended climatic situation to create more appropriate results. Until now, the presented equations are applicable for the climatic region of Central Europe only, but the developed methodology can be easily expanded to any geographical region.

Thus far, evapotranspiration of raingardens (made of natural grown soil) seemed to be estimated quite low, when calculated with the radiation equation by Makkink 
(0.12 mm/day). Until now, it was not possible to determine evapotranspiration of an infiltration area constructed with technical soils. The new equations for technical soils calculated an evapotranspiration rate of $3.15 \mathrm{~mm}$ /day (E2), which is about 30 times higher than the value of the common equations for calculating evapotranspiration.

It can be also seen that there is a variation in evapotranspiration, due to the different types of technical soils. The here used technical soils were mineral planting substrates with characteristics of high infiltration rate, water absorption capacity, and pore volume. Differences in grain size distribution, roughness (surface of the whole technical soil and each component), amount of grain size $<0.06 \mathrm{~mm}$, and organic matter influenced the evapotranspiration $[39,43]$.

Another aspect influencing evapotranspiration were the plants used for these test series (see Table 1). Depending on the type of photosynthesis, there were great differences in the optimum temperature and the correlating level of evapotranspiration [27]. Plants of photosynthesis type C3 (e.g., Geranium $x$ cantabrigiense) transpired more water at a temperature of $25^{\circ} \mathrm{C}$ (E3 and E6), whereas technical soils planted with CAM plants (e.g., Sedum floriferum) transpired even less (E2 and E5) than a non-planted substrate (E1 and E4) due to their high water-efficiency, and wind and radiation protection.

Tan et al. [30] also followed the idea of measuring evapotranspiration while using load cells. In their studies, they measured water loss of technical soils (filled in a tray of 0.5 by $0.5 \mathrm{~m}$ ) with three different plant species (Phyllanthus cochinchinensis, Heliconia 'American Dwarf', and Sphagneticola trilobata) to determine evapotranspiration of an extensive roof. Cells were placed next to the extensive roof to have the same conditions. Weight was measured every $20 \mathrm{~s}$ and averaged to minute- and hourly-intervals. As a result of these measurements, they were able to determine evapotranspiration over time for this specific green roof [30]. Still, their equation for calculation evapotranspiration is not completely transferable to different technical soils and for different climate scenarios. The outdoor test series of their study and the use of only one technical soil do not allow a transferability to other technical soils and climate scenarios.

In our test series, $10 \mathrm{~L}$ pots with a height of about $30 \mathrm{~cm}$ were used for calculating evapotranspiration of technical soils and corresponding plants. In practical application, a soil layer with a height of $30 \mathrm{~cm}$ is required by regulations in Austria [17]. The pots were not rooted by the plants through the whole pot and evapotranspiration was only measured for $24 \mathrm{~h}$, which does not allow a complete drying of the used technical soil. However, if there are multilayered technical soils or further developed plants used, pot size has to be adapted to plant size, to deliver more precise results.

Evapotranspiration has a large impact on the cooling of urban climate [44-46]. Studies in Shenzhen (China) show that two urban hedges (Hymenocallis littoralis of $0.4 \mathrm{~m}$ height and Ligustrum quihoui of $0.5 \mathrm{~m}$ height, both of an area of $40 \mathrm{~m}^{2}$ ) were able to cool down the underlaying surface more than $19^{\circ} \mathrm{C}$. The hedge, which showed higher evapotranspiration, also showed a larger effect of cooling [46]. Hence, knowledge on evapotranspiration may contribute to the calculation of the cooling capacity of urban areas as evapotranspiration is one key factor of different simulation tools for urban microclimate [47,48].

Planted infiltration areas have a large impact on local microclimate through cooling via evapotranspiration [49]. To provide the positive effects on the microclimate, plants need enough water. To ensure the water availability, the calculation of evapotranspiration helps to determine water loss of plants and used technical soil.

Additionally, the calculation of evapotranspiration can be important to measure the size of infiltration areas. Thus far, standards and regulations do not include evapotranspiration in the planning process [17]. However, considering evapotranspiration would slightly reduce the necessary volume for water storage in the infiltration area and could be used to implement more infiltration areas.

The here presented equations were especially applicable for single-layered systems, equipped with technical soils and C3 or CAM plants (especially for Geranium x cantabrigiense and Sedum floriferum), because in these test series, the test set-up was designed for these two 
plant types and single-layered technical soils. However, the created equation also has great relevance for $\mathrm{C} 4$ plants and any other technical soil, because the delivered results using the presented equation are even far more suitable for determining evapotranspiration of technical soils than using already existing ones, as it is shown in the comparison to the equation by Makkink. For more precise results, the required plant type (C4) or technical soil (multilayered systems) has to be tested in a climate chamber analog to the proposed method. Furthermore, the equations can be used for various sustainable rainwater management systems, as well as for green roofs and green facades. For example, the developed technical soils offered ideal living conditions for street trees, as shown in the test series in Vienna (Austria) [39]. Because of the limited size of the climate chamber, no trees or multilayered technical soils were tested during the test series.

Future research should adapt the equations to other rainwater management systems to include multilayer constructions, such as the Stockholm System with different layers of technical soil (planting soil, layer of crushed rock for infiltration of surface water, and airing of soil, structural soil: crushed rock 100/150 filled with fine soil particles) [50] or various systems of green roofs and green facades.

\section{Conclusions}

Evapotranspiration is a key factor for the improvement of urban climate. However, the calculation of evapotranspiration is difficult. This article presents a new, simpler approach to design equations for calculating evapotranspiration for any technical soil or plant. Each equation for calculating evapotranspiration can only be used under the conditions it was developed in. Here, the comparison of already existing equations to the newly developed ones shows this effect clearly.

Different equations for technical soils used in raingardens and tree plantings are presented and compared to the existing equation of radiation by Makkink. The great differences in results underline the fact once more to develop equations for technical soils. Therefore, the hypothesis that great differences in evapotranspiration between the equation of radiation by Makkink and the newly developed one are expected can be supported.

The results underline the relevance of the newly developed equations for calculating evapotranspiration loss of technical soils. The developed equations cannot only be used for applications outside, but in any area where technical soils are involved (e.g., calculating evapotranspiration of indoor greeneries, infiltration areas, building greeneries). By using the presented method, an equation for calculating evapotranspiration for any kind of technical soil and plant can be established.

Future research should assess the transferability of the developed equations for equations to calculate more complex rainwater management systems, such as multi-layer systems such as the Stockholm System, street trees, and indoor greeneries.

Overall, these are the five key findings of this research work:

- Due to the extreme condition for plantings in cities, new solutions for technical soils with specific features concerning their composition (e.g., water retention capacity, water permeability, pollutant retention, carrying capacity) are needed.

- Already existing well-known equations for calculating evapotranspiration cannot be used for technical soils because of their poor transferability.

- Newly developed and easily applicable equations for calculating evapotranspiration of different technical soils and plants were presented.

- There are large differences in results concerning evapotranspiration of the new equations and well-known ones.

- While using the presented method, easily applicable equations can be established for all kinds of technical soils and plants.

Author Contributions: Conceptualization, O.W. and U.P.; methodology, O.W.; validation, O.W., P.M., and U.P.; formal analysis, O.W.; investigation, O.W.; data curation, O.W.; writing-original draft preparation, O.W. and P.M.; writing-review and editing, O.W., P.M., B.S., and U.P.; visualization, 
O.W. and P.M.; supervision, B.S. and U.P.; project administration, O.W.; funding acquisition, B.S. and U.P. All authors have read and agreed to the published version of the manuscript.

Funding: This research received no external funding.

Institutional Review Board Statement: Not applicable.

Informed Consent Statement: Not applicable.

Data Availability Statement: The data presented in this study are available in this article.

Acknowledgments: Open access funding provided by BOKU Vienna Open Access Publishing Fund.

Conflicts of Interest: The authors declare no conflict of interest.

\section{References}

1. Dankers, R.; Hiederer, R. Extreme Temperatures and Precipitation in Europe: Analysis of a High-Resolution Climate Change Scenario. JRC Sci. Tech. Rep. 2008, 1-66.

2. Valipour, M.; Bateni, S.M.; Jun, C. Global Surface Temperature: A New Insight. Climate 2021, 9, 81. [CrossRef]

3. Stoffel, M.; Stephenson, D.B.; Haywood, J.M. Antipyretic Medication for a Feverish Planet. Earth Syst. Environ. 2020, 4, 757-762. [CrossRef]

4. Voigt, A.; Lampert, M.; Breuste, J. Anpassung an den Klimawandel als Aufgabe für eine ökologisch orientierte Stadtentwicklung. SIR Mitt. Ber. 2009, 38, 181-190.

5. Liu, Y.; Xiao, J.; Ju, W.; Xu, K.; Zhou, Y.; Zhao, Y. Recent trends in vegetation greenness in China significantly altered annual evapotranspiration and water yield Recent trends in vegetation greenness in China significantly altered annual evapotranspiration and water yield. Environ. Res. Lett. 2016, 11, 1-14. [CrossRef]

6. Li, G.; Zhang, F.; Jing, Y.; Liu, Y.; Sun, G. Science of the Total Environment Response of evapotranspiration to changes in land use and land cover and climate in China during 2001-2013. Sci. Total. Environ. 2017, 597, 256-265. [CrossRef] [PubMed]

7. Grimm, K. Integratives Regenwassermanagement: Motivenbericht; Magistrat der Stadt Wien; Wiener Umweltschutzabteilung-MA 22: Vienna, Austria, 2010; pp. 1-104.

8. Allen, R.G.; Pereira, L.S.; Raes, D.; Smith, M. FAO Irrigation and Drainage Paper No. 56 Crop Evaporation: Guidelines for Computing Crop Water Requirements; FAO: Rome, Italy, 1998; pp. 1-300.

9. Murata, T.; Kawai, N. Degradation of the urban ecosystem function due to soil sealing: Involvement in the heat island phenomenon and hydrologic cycle in the Tokyo metropolitan area. Soil Sci. Plant Nutr. 2018, 64, 145-155. [CrossRef]

10. Elhaus, D. Erosionsgefährdung; Geologischer Dienst NRW: Krefeld, Germany, 2015; pp. 1-32.

11. Fohrer, N.; Bormann, H.; Miegel, K.; Casper, M.; Bronstert, A.; Schumann, A.; Weiler, M. Hydrologie, 1st ed.; Fohrer, N., Ed.; Haupt: Bern, Switzerland, 2016; ISBN 978-3-8252-4513-9.

12. Deeb, M.; Groffman, P.M.; Blouin, M.; Perl Egendorf, S.; Vergnes, A.; Vasenev, V.; Cao, D.L.; Walsh, D.; Morin, T.; Séré, G. Using constructed soils for green infrastructure Challenges and limitations. Soil 2020, 6, 413-434. [CrossRef]

13. Morel, J.L.; Chenu, C.; Lorenz, K. Ecosystem services provided by soils of urban, industrial, traffic, mining, and military areas (SUITMAs). J. Soils Sediments 2015, 15, 1659-1666. [CrossRef]

14. Ebrahimian, A.; Wadzuk, B.; Traver, R. Evapotranspiration in green stormwater infrastructure systems. Sci. Total Environ. 2019, 688,797-810. [CrossRef]

15. Yilmaz, D.; Cannavo, P.; Séré, G.; Vidal-Beaudet, L.; Legret, M.; Damas, O.; Peyneau, P.E. Physical properties of structural soils containing waste materials to achieve urban greening. J. Soils Sediments 2018, 18, 442-455. [CrossRef]

16. Austrian Standards ÖNORM B 2506-3: Regenwasser-Sickeranlagen für Abläufe von Dachflächen und Befestigten Flächen-Teil 3: Filtermaterialien-Anforderungen und Prüfmethoden; Austrian Standards Institute: Vienna, Austria, 2018; pp. 1-26.

17. Austrian Standards ÖNORM B2506-1: Regenwasser-Sickeranlagen für Abläufe von Dachflächen und befestigten Flächen-Teil 1 Anwendung, Hydraulische Bemessung, Bau und Betrieb; Austrian Standards Institute: Vienna, Austria, 2013; pp. 1-22.

18. FLL. Empfehlungen für Baumpflanzungen Teil 2: Standortvorbereitungen für Neupflanzungen Pflanzgruben und Wurzelraumerweiterung, Bauweisen und Substrate; Forschungsgesellschaft Landschaftsentwicklung Landschaftsbau e.V.: Bonn, Germany, 2010; pp. 1-64.

19. Weiss, O.; Scharf, B.; Pitha, U. Evapotranspiration of Technical Substrates Methodology for Calculating Evapotranspiration of Technical Substrates. J. Ecol. Eng. 2019, 20, 28-37. [CrossRef]

20. Schrödter, H. Verdunstung Anwendungsorientierte Meßverfahren und Bestimmungsmethoden, 1st ed.; Springer: Berlin/Heidelberg, Germany, 1985; pp. 1-190.

21. Valipour, M. Ability of Box-Jenkins Models to Estimate of Reference Potential Evapotranspiration (A Case Study: Mehrabad Synoptic Station, Tehran, Iran). IOSR J. Agric. Vet. Sci. 2012, 1, 1-11. [CrossRef]

22. Rana, G.; Katerji, N.; Lazzara, P.; Ferrara, R.M. Operational determination of daily actual evapotranspiration of irrigated tomato crops under Mediterranean conditions by one-step and two-step models: Multiannual and local evaluations. Agric. Water Manag. 2012, 115, 285-296. [CrossRef]

23. Jacobs, A.F.G.; De Bruin, H.A.R. Makkink's equation for evapotranspiration applied to unstressed maize. Hydrol. Process. 1998, 12, 1063-1066. [CrossRef] 
24. Climate Service Center Germany. Verdunstung. Available online: https://www.climate-service-center.de/products_and_ publications/publications/detail/063226/ (accessed on 3 May 2021).

25. Hoermann, G. Speichermodelle zum Bodenwasserhaushalt. Simpel 2005, 1-61.

26. Jhajharia, D.; Dinpashoh, Y.; Kahya, E.; Singh, V.P.; Fakheri-Fard, A. Trends in reference evapotranspiration in the humid region of northeast India. Hydrol. Process. 2012, 26, 421-435. [CrossRef]

27. Weiler, E.W.; Nover, L.; Nultsch, W. Allgemeine und Molekulare Botanik, 1st ed.; Georg Thieme: Stuttgart, Germany, 2008; ISBN 3131476613.

28. Campbell, G.S.; Norman, J.M. An Introduction to Environmental Biophysics; Springer: New York, NY, USA, 1998.

29. Fiedler, H. Böden und Bodenfunktionen in Ökosystemen, Landschaften und Ballungsgebieten; Expert Verlag: Renningen, Germany, 2001.

30. Tan, C.L.; Wong, N.H.; Jusuf, S.K.; Chiam, Z.Q. Impact of plant evapotranspiration rate and shrub albedo on temperature reduction in the tropical outdoor environment. Build. Environ. 2015, 94, 206-217. [CrossRef]

31. Kaiser, D.; Köhler, M.; Schmidt, M.; Wolf, F. Increasing Evapotranspiration on Extensive Green Roofs by Changing Substrate Depths, Construction, and Additional Irrigation. Buildings 2019, 9, 173. [CrossRef]

32. Tukimat, N.N.A.; Harun, S.; Shahid, S. Comparison of different methods in estimating potential évapotranspiration at Muda Irrigation Scheme of Malaysia. J. Agricuktural Rural Dev. Trop. Subtrop. 2012, 113, 77-85.

33. Nolz, R.; (Institute for Soil Physics and Rural Water Management (SoPhy), University of Natural Ressources and Life Sciences Vienna, Austria). Personal communication, 2017.

34. ZAMG. Witterungsübersicht für das Jahr 2015. Available online: https://www.zamg.ac.at/zamgWeb/klima/klimarueckblick/ archive/2015/wiewars15.pdf (accessed on 3 May 2021).

35. Kuttler, W. Das Ruhrgebiet im Wandel Bestandsaufnahme und Prognose. UNIKATE 2010, 38, 41-51.

36. Orlik, A.; (Section Climatology, Division Customer Service, ZAMG Zentralanstalt für Meteorologie und Geodynamik). Personal communication, 2018.

37. Hottinger Baldwin Messtechnik GmbH (HBM) Data Sheet PW10A Single Point Load Cell. Available online: https:/ /www.hbm. com/fileadmin/mediapool/hbmdoc/technical/B02190.pdf (accessed on 27 May 2021).

38. Graf, R. Pflanzen für Versickerungsflächen Weiterführende Vegetationsuntersuchungen an einer Versuchsfläche in OberGrafendorf/Niederösterreich. Master's Thesis, University of Natural Resources and Life Sciences, Vienna, Austria, 2018; pp. 1-163.

39. Lübke, K. Dezentrales Regenwassermanagement in der Stadt Multifunktionale Sickerflächen. Master's Thesis, University of Natural Resources and Life Sciences, Vienna, Austria, 2019; pp. 1-200.

40. Weiss, O. Evapotranspiration von Technischen Substraten. Master's Thesis, University of Natural Resources and Life Sciences, Vienna, Austria, 2017; pp. 1-139.

41. FLL. Dachbegrünungsrichtlinien; Forschungsgesellschaft Landschaftsentwicklung Landschaftsbau e.V.: Bonn, Germany, 2018; pp. 1-118.

42. Cristea, N.C.; Kampf, S.K.; Burges, S.J. Revised Coefficients for Priestley-Taylor and Makkink-Hansen Equations for Estimating Daily Reference Evapotranspiration. J. Hydrol. Eng. 2013, 18, 1289-1300. [CrossRef]

43. Kos, B. Untersuchungen zu Baumsubstraten und Straßenbäumen Mittels Ausgewählter Geotechnischer und Vegetationstechnischer Methoden im Rahmen des SAVE Projekts der Stadt Wien Research of tree Substrates and Street-Trees with Geotechnical and Vegetation- Techn. Master's Thesis, University of Natural Resources and Life Sciences, Vienna, Austria, 2017.

44. Jim, C.Y. Assessing climate-adaptation effect of extensive tropical green roofs in cities. Landsc. Urban Plan. 2015, 138, 54-70. [CrossRef]

45. Jim, C.Y.; Tsang, S.W. Modeling the heat diffusion process in the abiotic layers of green roofs. Energy Build. 2011, 43, 1341-1350 [CrossRef]

46. Zou, Z.; Yang, Y.; Qiu, G.Y. Quantifying the evapotranspiration rate and its cooling effects of urban hedges based on threetemperature model and infrared remote sensing. Remote Sens. 2019, 11, 202. [CrossRef]

47. Gros, A.; Bozonnet, E.; Inard, C.; Musy, M. Simulation tools to assess microclimate and building energy A case study on the design of a new district. Energy Build. 2016, 114, 112-122. [CrossRef]

48. Huttner, S. Further Development and Application of the 3D Microclimate Simulation ENVI-Met; Johannes Gutenberg-Universitat in Mainz: Mainz, Germany, 2012; Volume 147.

49. Hunt, W.F.; Lord, B.; Loh, B.; Sia, A. Plant Selection for Bioretention Systems and Stormwater Treatment Practices, 1st ed.; Springer: Singapore; Berlin/Heidelberg, Germany; New York, NY, USA; Dordrecht, The Netherlands; London, UK, 2015; ISBN 9789812872449.

50. Embrén, B.; Alvem, B.M.; Stal, Ö.; Orvesten, A. Planting Pits in the City of Stockholm An Handbook; City of Stockholm: Stockholm, Sweden, 2009; pp. 1-83. 